Research.

\title{
Influence analysis of ownership structure on manufacturing company's performance in Indonesia 2012 - 2013
}

\author{
Darwin Marasi Purba \\ Department of Accounting, Economic College of Binaniaga, Bogor, Indonesia \\ mazmur.911516@gmail.com \\ Jhon Herlan Sianturi \\ jhonherlan16@gmail.com
}

Received: July 25, 2019; Accepted: August 12, 2019; Published: December 31, 2019

To cite this article: Purba, Darwin Marasi, Jhon Herlan Sianturi. 2019. Influence analysis of ownership structure on manufacturing company's performance in Indonesia 2012 - 2013. The Accounting Journal of BINANIAGA. 4 (2): 47-60. doi: 10.33062/ajb.v4i2.341

Abstract. The purpose of this study is to analyse the effect of ownership structure on profitability in the manufacturing sector listed in Indonesia Stock Exchange (BEI). Independent variables used for this study consist of institutional ownership, foreign ownership, and pubic ownership. Profitability is measured by ROA (Return On Assets). While leverage as firm size is used as the control variable. This research uses secondary data, namely the annual financial statements of listed manufacturing companies in Indonesia Stock Exchange for the years 2012, and 2013. The sampling method used was purposive sampling and data analysis model used was multiple regression analysis. Results from this study indicate that institutional ownership in a company has a positive and significant effect on firm performance. Meanwhile, the foreign ownership and public ownership has no a positive effect on firm perforrmance in a company.

Keyword: Ownership structure, Return on assets (ROA), Firm performance.

\section{Introduction}

Weakness of management system in the companies has been the reason of economic crises in Indonesia. (Dickinson and Mullineux, 2001; Capulong et al. 2000; Johnson et.al, 2000) Issue of weak corporate governance has been coming up due to segregation between the owner of a company and control the company. One of the most important issue and controversial about corporate governance is about the structure of shareholders related to the improvement of company performance. Referring to D'Souza et.al (2006) ,any change of the owners has caused corporate governance management change as well. The possibility of a company under pressure in finance has been influenced mostly by the structure of company owners. The structure of company owners has described the commitment of the owners to safe the company. (Wardhani, 2005). Referring to Wahyudi and Pawesti (2006), Some researchers have believed that the owners structure is able to influence company management running the business and at the end it will influence the company performance achieving company goals to maximize the value of company. It has happened due to control system they have had.

The owners structure in Indonesia has a different characteristic compared with the companies in other countries. Mostly the companies in Indonesia has tended to be concentrated where the founders can be in the position of board of directors or commissionaires, and in spite of it, conflict of agency may coming up between managers

Darwin Marasi Purba and Jhon Herlan Sianturi. Influence Analysis of Ownership Structure on Manufacturing Company's Performance in Indonesia 2012 - 2013 
and the owners, between majority shareholders and minority shareholders. Referring to Jensen \& Meckling (1976), agency conflict has been coming up due to the separation between the owners of the company and company control. As mentioned on the theory or agency, it is describing about how the related parties in the company which is managers, owners of the company and creditors should have to conduct, because, as a matter of fact they are having different interests.

Previous phenomena and some researches which have described before about the structure of owners of the company, therefore, the researcher is interested in doing further research about the effect of ownership structure upon the company performance. It is because the result of previous research about the effect of ownership structure upon the company performance has indicated inconsistency circumstances. The differences between this research and previous researches are as follows: 1 . This research has divided each variable of ownership structure which had been studied before by former researchers which is institutional ownership, managerial ownership, foreign ownership and government ownership. 2. The researcher has appointed one new independent variable which is public ownership and added one variable of control which is leverage. 3 . This research has applied data from BEI years 2012 - 2013 that has never been applied by former researchers.

\section{Library Review}

\section{Agency Theory}

In modern economy, management, and company management has been separated from the owners of company. It is getting along with Agency theory that has found out that shareholders should have given the authority to manage the company to professional experts (agents) who are fully understanding about running the business in daily basis. The objectives of management separation of the owners of company are expecting that the company will get maximum profit but efficient cost because it is wellmanaged by professional experts. They are professional experts who are responsible for the company and are having fully authority to manage the company, nevertheless, professional experts have been being the agents of shareholders. The bigger the company is well-managed, the bigger the profit will be obtained. However, the shareholders or owners of the company are only responsible for controlling and monitoring company running well managed by the management and developing incentive system for the management to make sure that they are working for the company purposes. (Adrian Sutedi, 2011: 13)

On the other side, within a company, the managers have tended to have their own interest to maximize personal welfare instead of maximizing the shareholders welfare. Managers are given fully authority by shareholders to make any decision which is it has created potential conflict of interest that is well-known in the agency theory (Brigham and Houston, 2011).

Ali stated in Bayu (2010) said that authorized managers are managing the company and are responsible for maximizing principal profit and reporting their responsibility thru financial reporting media. Referring to the managers performance, management compensation is given according to the contract agreed. However, there are two different kind of interests in the company for them to reach the achievement or to maintain prosperity level expected.

Referring to Sefiana (2009), perspective of agency theory is the basic thing to understand about corporate governance issue and earning management. Agency theory has created asymmetric relationship between the owners and the management, in order to avoid any asymmetric circumstance a concept of Good Corporate Governance is required to make a company more healthy. The implementation of good corporate governance is based on the agency theory that can be explained as the relationship

Darwin Marasi Purba and Jhon Herlan Sianturi. Influence Analysis of Ownership Structure on Manufacturing Company's Performance in Indonesia 2012 - 2013 
between management and the owners, management as company's agent is having moral responsibility to optimize company earnings which is the principal earnings and as the reward, the management has received the acceptable compensation according to the contract agreed. However, there are two different interests within the company, each party has tried to fulfill their need. As a matter of fact, the information about asymmetric circumstance has come up between management and the owners who has given an opportunity for the managers to run the company getting more earnings, on the other side, the management might provide unclear performance report of the company.

Referring to the company context, agency problem has made the investors more carefully investing their money to avoid any mismanagement of their investment (Wulandari, 2011)

\section{a. Company Performance}

Actually, we need to know about performance. In relation with performance understanding, some definitions had been defined by some experts, refers to Mulyadi (2007:337), job performance is the success of personnel, team, or organization unit to make strategic target designed come true and in compliance with acceptable behavior.

Bastian (2006274) described that Job Performance is an overview of activities/program/policies achievement reaching the target, objectives, mission and vision of the organization. All the lists to be achieved are designed on the strategic planning of an organization. In general, job performance is an achievement of company goals at a certain period.

Rivae, et al. (2008:14) described that Job Performance is the result to what extent someone's achievement is gained for a certain period in performing his duty comparing with other probabilities, such as, standard of achievement, targets or goals or criteria designed before and agreed by the company.

b. Institutional Ownership

Referring to Jensen and Meckling (in Kartikawati, 2007) described that institutional ownership is an important role to minimize agency conflict happened between shareholders and managers. Institutional investor existence is considered be able to optimize the supervision of management job performance by monitoring every decision taken by the management of the company. Research of Kartikawati (2007) indicated that institutional ownership has affected positively financial performance of the company.

Referring to Shien, et al., (in Winanda, 2009) described that institutional ownership is the ownership of company's shares owned by finance institutions such as insurance companies, banks, pension fund, banking investment, finance institution, legalized institution, trust fund and other institutions at year-end. One factor that can affect the company performance is the institutional ownership. Institutional ownership existence in a company will drive the increasing of supervision more optimum upon management's job performance, because shareholders are representing a powerful resource which can be used to support or not support the management job performance. Controlling done by the institutional investors is depending on the big investments invested.

Referring to Solomon (in Sabrina, 2010) described that the bigger the institutional financial ownership, the stronger the power they have to control the management and as the result, it will drive stronger power to optimize the value of company, so that company performance will increase accordingly. The effect of institutional investors upon company management could be very important to be used which is management interest can be getting along with shareholders interest.

Referring to Desmiyawati et,al.(2013), the significance of institutional ownerships as controlling agents are based on how big investment they invested in

Darwin Marasi Purba and Jhon Herlan Sianturi. Influence Analysis of Ownership Structure on Manufacturing Company's Performance in Indonesia 2012 - 2013 
capital market. When the investors are not satisfied with the managerial performance, they will sell their shares on the market.

Referring to Hanafi et.al.(in Sisca Christianty Dewi, 2008) explained that measuring variable of institutional ownership has applied the percentage of shares obtained from the total shares of the institution divided by all the total of shares circulating on the market.

\section{c. Foreign Ownership}

Referring to Jensen and Marketing (in Kartikawati, 2007), based on the agency theory, conflict of interests between managers and shareholders has caused agency conflict which is required mechanism tolls to be applied to protect the shareholders' interest.

Referring to Farooque et.al.(2007) described that foreign investors is a company belongs to a person, legal firm, government and other foreign company which is having all shares circulated on the market.

Referring to Li et.al. (in Fauzi, 2006) described that Foreign Ownership is a proportion of company's shares belongs to a person, legal firm, government which is foreign status. Or individual legal firm that is not coming from Indonesia, foreign ownership is a party which is concerned about the improvement of good corporate governance.

According to Majumdar et.al.(1999) found that foreign ownership had affected positively company performance in India. Therefore, the more the foreign investors, the more the increasing of company performance will be, it has happened due to foreign investors are having their own proper management system, technology and innovation, experts and better marketing which have been affecting positively the company.

Patibandla et.al.(2002) described that the problems which had caused company performance decreased were bad relationship between shareholders and manager, but if it were in a good relationship between shareholders and manager, company performance would be getting better. . The bigger the foreign ownerships, they will appoint expatriates to be their board of commissioners and directors to run the company to maximize the company performance which is it is getting along with their goals.

According to Douma et al. (2003) described that foreign ownerships have affected positively the company performance.

d. Public Ownership

Referring to Saleh (2004), the shareholders structure is an important thing to determine the value of a company. There are two aspects of ownership that have to be considered such as foreign party and local party or company management. Concentration of foreign ownerships can be measured by using the percentage of shareholders owned by external party. Concentration of internal ownerships can be measured by using the percentage of shareholders owned by internal party or management of a company. Foreign ownership has taken a big role to influence the company thru mass media such as criticism or comments which is considered as public voice.

Ali et.al (2008) described that big foreign ownerships have influenced the management which is formerly it has been managed according to the company purpose but now it has been managed limitedly.

Nur'aini (2010:25) described that in order to reach the main purpose of company, it has to improve the value of company and either internal financial support or external one is required, because financial support will be affecting capital

Darwin Marasi Purba and Jhon Herlan Sianturi. Influence Analysis of Ownership Structure on Manufacturing Company's Performance in Indonesia 2012 - 2013 
investment level.

Gladstone \& Gladstone (in Dini Nur'aini, 2010) described that low capital investment is one of the reasons why a company has failed. External financial support above can be obtained from public shares.

Referring to Purba (2004) explained that in order to drive real economy is not only coming from consumption, but also from investors fundamentally. Therefore, it will need quite long time and big efforts to recover people trust to invite more investors in real sectors.

Rosman (2007) said that public ownerships have been indicated by to what extent of which private information should have to be shared by the management to the public. Private information is an internal information which formerly has been only informed to the managers, such as measurement standard of company performance, bonus planning, etc.

\section{Framework Design}

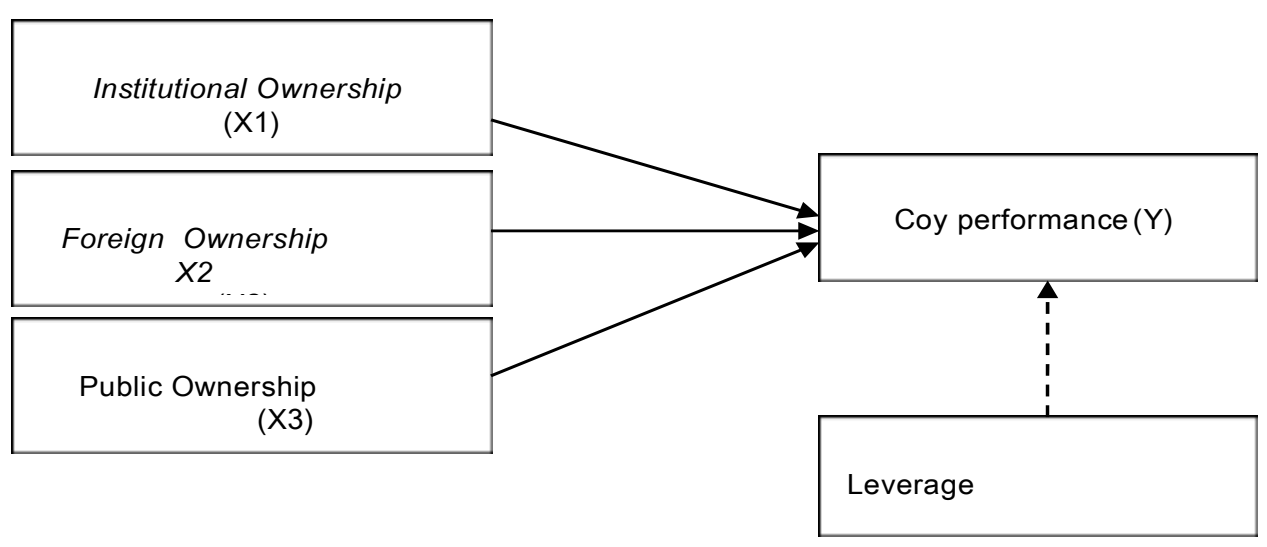

Drawing: Framework Design

\section{Research Design}

\section{Type of the Research}

This research has applied causal research design, refers to Sugiyono (2007:30)causal design is a research to analyze the causal-effect correlation between independent variable (affecting variable) and dependent variable (affected variable). This research has used quantitative data reserved to examine the effect of four independent variables upon one dependent variable. The three independent variables are institutional ownership variable (X1), foreign ownership variable (X2), and public ownership variable $(\mathrm{X} 3)$ which have affected one dependent variable of company performance $(\mathrm{Y})$.

\section{Definition and Variable Operationalization}

To understand the related variables and to provide a clear picture of research execution, the definition of variables being studied are defined as the following.

\section{Independent Variable (X)}

Independent variable is a free variable which is not relying on others such as:

a). Institutional Ownership (X1)

Institutional Ownership is the proportion of shares owned by the institution such as LSM(non profit organization), private company, stock-exchange institution, pension funds,

Darwin Marasi Purba and Jhon Herlan Sianturi. Influence Analysis of Ownership Structure on Manufacturing Company's Performance in Indonesia 2012 - 2013 
insurance company, bank and investment corporation. Institutional ownership is measured by using ratio between total of shares owned by the institution and total shares circulated on the market (Ujiyantho and Pramuka, 2007).

\section{Institutional Ownershiip = \\ Total shares owned by the Institution \\ Total shares circulated \\ $x 100 \%$}

b). Foreign Ownership (X2)

Foreign ownership is the proportion of outstanding shares owned by the investors or foreign investors such as companies owned by individual, legal office, government and its parties which have status abroad upon total of shares circulated on the market (Farooque, et.al. 2007).

\section{Total shares owned by foreign investors \\ Foreign ownership $=\frac{\text { Total of shares circulated }}{100 \%}$}

c). Public Ownership (X3)

Public ownership is total shares owned by public against all the shares they managed.

\section{Public Ownership $=\quad$ Total shares owned by public $\quad \times 100 \%$ \\ Total of shares circulated}

\section{Dependent Variable ( $\mathrm{Y}$ )}

Dependent variable is a variable which is relied on or is affected by independent variables. In this research, company performance is proxied by R.O.A. Return on Asset (ROA) is an earnings ratio after bank interest and tax (EAT) or earnings net divided by book value of the asset at the beginning of fiscal year. (Brigham \& Ehrhadrt, 2005).. The following equation is the calculation of $R O A$ ratio:

$$
\text { ROA }=\frac{\text { Profit after Tax }}{\text { Total aset }} \times 100 \%
$$

\section{Controlled Variable}

According to Sugiyono (2009) controlled variable is a variable being controlled or maintained constant, so that the correlation between independent variables and dependent variable is not affected by other factors which are not being studied if the researcher is going to do a comparison study.

Leverage has indicated the extent of which company assets have been obtained or financed by loans. Siallagan and Machfoedz (2006) dexcribed that leverage could minimize conflict of interest between managers and bondholders.

$$
\text { Leverag }=\frac{\text { Total Liabilities }}{\text { Total aset }} \times 100 \%
$$

\section{Variable Measurement}

Company performance is measured by using Return on Assets (ROA) which is the equation of net profit added by bank interest after tax and divided by total assets. The

Darwin Marasi Purba and Jhon Herlan Sianturi. Influence Analysis of Ownership Structure on Manufacturing Company's Performance in Indonesia 2012 - 2013 
bigger the ROA value of a company is, the bigger profit of a company will be and it will reduce the risk of the company. It has caused that the company having bigger ROA would have less equity cost and liability cost comparing to the company having smaller ROA. (Bhojraj and Sengupta, 2003:Francis, et al., 2005: Chen and Jian,2006: Byun et al., 2008). Size of a company is measured by using natural logarithm and total asset of the company. A company which is having bigger assets will be able to settle down all its liabilities for the next period. In spite of that, the bigger the total assets of a company, it is expected that the company will be giving return earnings to the investors more precisely. However, the company which is having bigger total assets would have had lower equity cost and liability cost (Bhojraj ann Sengupta, 2003; Francis, et al., 2005; Shuto and Kitagawa, 2010)

\section{Samples of the Research}

\section{Sample}

Sampling technics has applied purposive sampling method which is sampling method based on certain criteria, as the following:

a), Manufacturing companies listed on BEI which is having active shares in the stock market from 2010 to 2013.

b), Those companies have issued their yearly report period $2012-2013$.

c), Companies which their shares owned by institutional or foreign party.

d), Those companies have provided the information about their social responsibility and their proportion of shares.

\section{Method of Analysis}

In order to examine the effect of some independent variables upon a dependent variable, it has used multiple linear regression statistical tools. Data of this research are tested using some statistical test which consists of descriptive statistics and statistical test using hypotheses test. . This statistical test is to provide big picture of profile data of the sample. In this case, the researcher has applied descriptive statistics consisting of average, standard deviation, minimum and maximum.

\section{Result and Description}

Descriptive statistics on Table 1 has mentioned 40 samples of the research consisting of 135 companies listed in Jakarta Stock Exchange in 2012 and 2013. Result of descriptive test has identified that shares owned by Institutions (KINS) of manufacturing companies which is having $0 \%$ minimum level of shares ownership refers Goodyear Indonesia Ltd (GDYR) and 3.87\% maximum level of shares ownership refers to Pan Brothers Ltd.(PBRX), and on average of 40 samples of manufacturing companies has indicated $11.2 \%$ of shares institutional ownership(KINS) explaining that it has indicated $11.4 \%$ standard deviation of change in companies ownership.

Table. Descriptive Statistics

\begin{tabular}{|l|r|r|r|r|r|}
\hline \multicolumn{7}{|c|}{ Descriptive Statistics } \\
\hline & $\mathrm{N}$ & \multicolumn{1}{|c|}{ Minimum } & \multicolumn{1}{c|}{ Maximum } & \multicolumn{1}{c|}{ Mean } & \multicolumn{1}{c|}{ Std. Deviation } \\
\hline KINS & 40 & .000 & .387 & .11236 & .113846 \\
\hline KASIG & 40 & .002 & 3.906 & .44523 & .871776 \\
\hline KPUB & 40 & .000 & 1.494 & .22883 & .364268 \\
\hline ROA & 40 & .003 & .254 & .06467 & .071876 \\
\hline LEV & 40 & .079 & .881 & .47217 & .178420 \\
\hline Valid N (listwise) & 40 & & & & \\
\hline
\end{tabular}

Source: Data processed SPSS 21.

Darwin Marasi Purba and Jhon Herlan Sianturi. Influence Analysis of Ownership Structure on Manufacturing Company's Performance in Indonesia 2012 - 2013 
Data of Foreign Ownership (KASIG) indicating that minimum level of ownership of $0.2 \%$ refers to Multi Prima Sejahtera Ltd (LPIN) and maximum level of ownership of $390.6 \%$ refers to Keramika Indonesia Association Ltd (KIAS), it has indicated that shares owned by foreign ownership is $44.5 \%$ and standard of deviation of $87.2 \%$.

Data of shares owned by public (KPUB) indicating that $0 \%$ minimum ownership level refers to Selamat Sempurna Ltd (SMSM) and 149.4\% maximum ownership level refers to Siearad Produce Ltc (SIPD) indicating that public shares ownerships has on average $22.9 \%$ of ownership level and $36.4 \%$ standard of deviation.

Result of ROA, dependent variable has indicated that $0.3 \%$ minimum of ROA refers to Polychem Indonesia Ltd (ADMG) and $25.4 \%$ maximum of ROA refers to Selamat Sempurna Ltd (SMSM), average of ROA is $6.5 \%$ and standard of deviation is $7.2 \%$.

\section{Hypothesis Test and Description}

\section{1), Determinant Coefficient Test $\left(R^{2}\right)$}

This hypothesis test is in compliance with the hypothesis which has been determined before, which is using multiple linear regression equation. This test is measuring to what extent the capability of this model is able to describe any dependent variable variation.. Small $R$ value has indicated that the capability of independent variables describing dependent variable limitedly. Value of $R$ square is applied to recognize the effect of additional one independent variable being put into a regression equation. The calculation of $R$ square has applied an indicator which is adjusted $R$ Square.

Table.

Test Result of Determinant Coefficient (R2)

\begin{tabular}{|l|c|c|l|}
\hline \multicolumn{2}{|c|}{ Model Summary } \\
\hline Model & $\mathrm{R}$ & $\begin{array}{l}\text { Adjusted } \\
\text { R Square }\end{array}$ & Description \\
\hline 1 & 0.743 & 0.501 & $\begin{array}{l}\text { Independent variables have affected } 50.1 \% \text { (rounded) } \\
\text { dependent variable }\end{array}$ \\
\hline
\end{tabular}

a. Predictors: (Constant), LEV, KPUB, KINS, KASIG

b. Dependent Variable: ROA Source : data processed SPSS 21

Based on Table 2 above, correlation $(R)$ coefficient value of 0.743 indicating that independent variable is only able to describe dependent variable of $74.3 \%$, however, the remaining ones are affected by other factors. . Value of adjusted $R$ Square of 0.501 indicating that independent variables of KINS, KASIG and KPUB have influenced $50 \%$ (rounded) only the company performance (ROA) or they only can describe $50 \%$ of dependent variable variation, but the rest of $50 \%$ is affected by other factors which are not being studied.

\section{2), F Statistical Test}

Actually, $\mathrm{F}$ statistical test indicating that all independent variables which are in the model have affected simultaneously all dependent variables (Ghozali, 2006) 
Table.

Result of simultaneous F test or ANOVA Test.

\begin{tabular}{|l|c|c|l|}
\hline \multicolumn{3}{|c|}{ ANOVA } \\
\hline Model & $\mathrm{F}$ & Sig. & Note \\
\hline 1 Regression & 2.655 & 0.049 & $0.049<0.05 \mathrm{HO}$ rejected \\
\hline
\end{tabular}

a. Dependent Variable: ROA

b. Predictors: (Constant),LEV, KPUB, KINS, KASIG

c. Source : data processed SPSS 21

Refers to Table 3, F test indicating F-count value of 2.655 and sig.value of $0049<$ probability value of 0.05 , therefore, Ho is rejected. Since probability value is less than 0.05 or $5 \%$, it has concluded that independent variables such as structure of institutional ownership, structure of foreign ownership and structure of public ownership simultaneously have affected dependent variable which is company performance or Return On Assets.

\section{3) t-test}

As a matter of fact, t-test has indicated the extent of which one variable partially has described the variation of dependent variable (Ghozali, 2006).

Table.

Result of Partial Test (t-test)

\begin{tabular}{|c|c|c|c|l|}
\hline \multicolumn{5}{|c|}{ Coefficients } \\
\hline Model & B & Beta & Sig & Description \\
\hline (Contanta) & 0.139 & & & \\
\hline KINS & 0.160 & 0.253 & 0.100 & Sig $0.100>0.05$, Ho accepted \\
\hline KASIG & -0.025 & 0.304 & 0.098 & Sig $0.098>0.05$, Ho accepted \\
\hline KPUB & 0.005 & 0.027 & 0.864 & Sig $0.098>0.05$, Ho accepted \\
\hline
\end{tabular}

a. Dependent Variable: ROA

\section{Source : Data processed SPSS 21}

Table, based on the Output Coefficient above, test result of multiple linear regression has indicated as the following:

1) Value (constant) has indicated the value of 0.139 describing that all independent variables value is nul(0), however, dependent variable value (Beta) is 0.139 , it has explained that if ratio of KINS, KASIG, and KPUB is nul (0), ROA ratio will increase $14 \%$ (rounded)

2) Regression coefficient value of Structure Institutional Ownership variable (KINS) of 0.160 which is positive value (+) has been indicating that an increasing of one unit value of KINS will increase $25 \%$ (rounded) of company performance (ROA ratio) Regression coefficient value of variable of Structure Foreign Ownership (KASIG) of -0.025 which is negative (-) will increase $1 \%$ value of Ratio variable KASIG, but it will decrease $30 \%$ (rounded) of the company performance (ROA Ratio).

3) Regression coefficient value of variable Structure Public Ownership (KPUB) of 0.005 which is positive (+) will increase $1 \%$ KPUB ratio and will increase $3 \%$ (rounded) company performance (ROA ratio).

\section{Hypotheses}

$\mathrm{HO}=$ Institutional Ownership $(\mathrm{X} 11)$ did not affect Company Performance.

$\mathrm{H} 1=$ Institutional Ownership (X1) has affected positively Company Performance.

$\mathrm{H} 0=$ Foreign Ownership (X2) did not affect Company Performance.

$\mathrm{H} 2$ = Foreign Ownership (X2) has affected positively Company Performance.

Darwin Marasi Purba and Jhon Herlan Sianturi. Influence Analysis of Ownership Structure on Manufacturing Company's Performance in Indonesia 2012 - 2013 
$\mathrm{HO}=$ Public Ownership (X3) did not affect Company Performance.

H3 = Public Ownership (X3) has affected positively Company Performance.

\section{Basic of Decision Making:}

$\mathrm{H} 0$ is accepted if $\mathrm{H} 1$ is rejected when Sig.value $>0.05$.

$\mathrm{H} 0$ is rejected if $\mathrm{H} 1$ is accepted when Sig. value $<0.05$

$\mathrm{H} 0$ is accepted if $\mathrm{H} 2$ is rejected when Sig.value $>0.05$.

$\mathrm{H} 0$ is rejected if $\mathrm{H} 2$ is accepted when Sig.value $<0.05$

$\mathrm{H} 0$ is accepted if $\mathrm{H} 3$ is rejected when Sig.value $>0.05$

$\mathrm{H} 0$ is rejected if $\mathrm{H} 3$ is accepted when Sig.value $<0.05$.

Referring to the test, test result of Hypotheses 1 to 3 can be summarized as mentioned on Table.

Table.

Test Result of Hypotheses

\begin{tabular}{|l|l|l|}
\hline Variable & Sig. (P-Value) & Result of the research \\
\hline 1. Institutional Ownership & 0,100 & $\begin{array}{l}\mathrm{H} 0 \text { is accepted } \mathrm{H} 1 \text { is } \\
\text { rejected }\end{array}$ \\
\hline 2. Foreign Ownership & -0.098 & $\begin{array}{l}\mathrm{H} 0 \text { is accepted H2 is } \\
\text { rejected }\end{array}$ \\
\hline 2. Public Ownership & 0.864 & $\begin{array}{l}\mathrm{H} 0 \text { is accepted H3 is } \\
\text { rejected }\end{array}$ \\
\hline
\end{tabular}

Source : Data processed SPSS 21

1) Institutional Ownership did not affect Company Performance (H1)

On the Table 5.11 above, Sig.value of Institutional Ownership is 0.100 and positive $(+)$, therefore, it can be concluded that Institutional Ownership (KINS) did not affect Manufacturing industry performance because KINS is having Sig.value $0.100>0.05$. This test is not getting along with the previous research done by Kartikawati (2007) found out that institutional ownership has positively affected Financial Performance. But on the contrary, Pound (1988), Sudarma (2004) found out that institutional ownership has negatively affected capital structure and company value.

\section{2) Foreign Ownershio did not affect Company Performance (H2)}

Sig.value of Foreign Ownership (KASIG) of -0.098 and negative (-) can determine that Foreign Ownership (KASIG) did not affect Manufacturing Industry because KASIG is having Sig.value of $0.098>0.05$. It is not getting along with the research of Chibber \& Majumdar (1999), Patibandla (2002), and Douma et al. (2003) who has found out that foreign ownership has positively affected Company Performance.

\section{3) Public Ownerhsip did not affect Company Performance (H3)}

Sig.value of Public Ownership of 0.864 and positive (+) can conclude that Public Ownership (KPUB) did not affect manufacturing industries, because its sig.value of $0.864>0.05$, and it is not getting along with the research done by Sudarman (2004) (quoted byNur'ani: 2010) describing that bigger public ownership will affect the increasing value of company.

Based on the regression equation above, the three independent variables which are KINS, KISIG and KPUB did not affect company performance, as Sig.value P-value) of KINS is 0.100 and positive value(+), KASIG is -0.098 and negative value (-), and KPUB is 0.864 and positive value $(+)$. 
Mathematic model of this research is as the following:

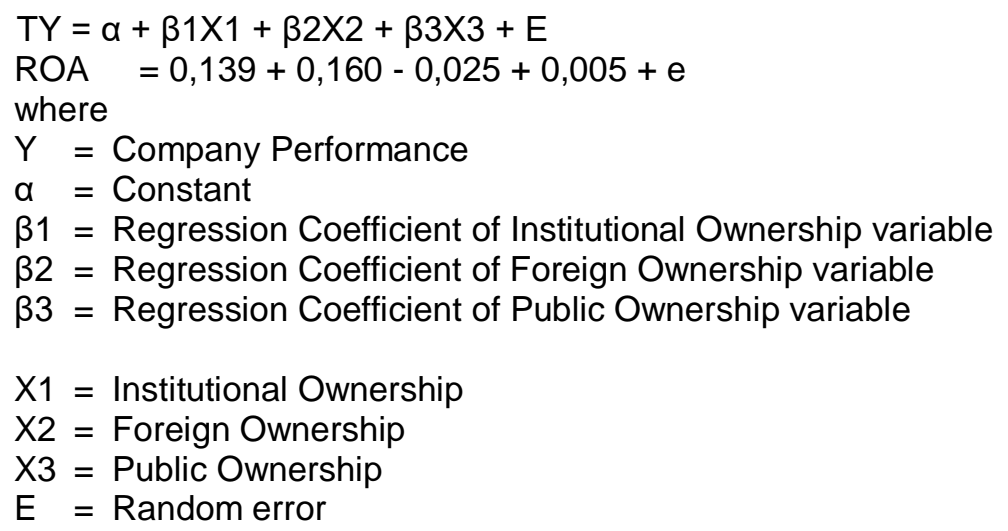

In accordance with the regression equation above, it has described $\alpha$ (constant) of 0.0139 indicating that regression coefficient of independent variables considered nul, however, on average ROA which is dependent variable is $14 \%$. KINS Regression coefficient of positive 0.160 has been indicating a positive correlation, and if KINS increases $1 \%$, then value of ROA which is dependent variable will increase $16 \%$ with the assumption that value of other independent variables are constant. KASIG coefficient of -0.025 and negative value indicating that if foreign ownership is increased one percent, then ROA which is dependent variable will decrease $3 \%$ with the assumption if value of other independent variables are constant KPUB coefficient value of 0.005 and positive has been indicating that public ownership has increased $0.5 \%$ with the assumption that $\alpha$ and regression coefficient of other variables are constant.

\section{Conclusion and Suggestion}

\section{Conclusion}

In compliance with the result of data analysis and the description described on previous chapters, the researcher is able to summarize results as follows:

1), Institutional Ownership did not affect Company Performance. Nevertheless, Institutional ownership involvement could not limit the behavior of opportunistic managers, it means that institutional ownership externally is unable monitoring the company. And the existence of institutional ownership did not prove that they had pushed to increase their control more optimum upon company performance to reach the goals of company. This research is not in accordance with the research of Ismiyanti and Mamduh (2003) and Slovin and Sushka (1993)indicated that institutional ownership of shares had affected positively the company value.. This finding is not also corresponding with the research of Kartikawati (2007), Pakaryaningsih (2008), Melinda (2008), Falzadeh (2011) and Nuriana (2012) who indicated that institutional ownership had been affecting positively company value.

2), Foreign Ownership did not affect company performance. This research is not corresponding with the research of Chibber \& Majundar (1999) and Kumar (2004), Patibandla (2002), and Douma et al..(2003) who has found out that foreign ownership has positively affected company performance, however, this research is corresponding with the research of Setiawan (2006) who has declared that foreign ownership has affected negatively company performance.

3), Public Ownership did not affect company performance. It did not getting along with the research done by Sudarman, 2004 (quoted by Nur'ani: 2010) mentioned that the bigger that public ownership will affect the increasing of company value.

Darwin Marasi Purba and Jhon Herlan Sianturi. Influence Analysis of Ownership Structure on Manufacturing Company's Performance in Indonesia 2012 - 2013 


\section{Suggestions}

This research has some limitation that is still required some corrections and development for future studies. Limitation of this research is mentioned on the following:

1), The samples used in this research were only manufacturing companies listed on the Indonesia Stock-Exchange, so that, it could not be used to generalize them, hopefully, next research will be able to do a research using different objects such as infrastructure companies, technology sector and communication sector to get more consistent result of the research.

2), Short period of time has caused low test, so that, the accuracy of information is still relatively small. Nevertheless, the researcher suggested that next research could use data of annual report with longer period of time in order to get much more samples obtained.

3), This research has only applied value of the company to evaluate company performance. For the future, the research can be enlarged by using the evaluation of financial ratio that can be used to evaluate company performance such as ROI, EOS, dividend policy, etc.

\section{References}

Anderson, R. C., Mansi, S. A., and Reeb, D. M. (2002). Founding Family Ownership and the Agency Cost of Debt. Journal of Financial Economics, 68, 263-285.

Andres,C. (2008). Family Ownership, Financing Contraints and Investment Decisions.

Working Paper University of Bonn Department of Economics, Germany.

Bathala, C.T., Moon, K.P., and Rao. R.P. (1994)."Managerial ownership, debt policy, and the impact of institutional holdings: An agency perspective". Financial Management, 23, 38- 50.

Benfratello, L. and Sembenelli, A. (2002). Foreign ownership and productivity;is the direction of causality so abvious?. Di unduh dari www.ssrn.com. 28 April 2013.

Bozec, Y. and Laurin, C. (2008). Large Shareholder Entrench and Performance: Emprical Evidance from Canada. Journal of Business Finance and Accounting 35(1), 2549.

Brigham, E.F. and Erhardt, M.C. (2005). Financial Management Theory and Practice,11th Edition, Ohio: South Western.

Cao, J. and Lerner, J. (2006). The Performance of Reverse Leveraged Buyouth. www. ssrn.com.

Capulong, M.,Edward,D.,Webb, D., and Zhuang, J. (eds). (2000). Corporate governance and finance in East Asia: A study of Indonesia, Republic of Korea, Malaysia, Philippines and Thailand. Asian Development Bank: Manila.

Chhibber, P. K. and Majumdar, S. K. (1999). Foreign ownership and profitability: property rights, control and the performance of firms in Indian Industry. Journal of Law and Economics, 46(3), 209-238. ISSN: 00222186.

Christiawan, Y. J. Dan Tarigan, J. (Mei 2007). Kepemilikan Manajerial: Kebijakan Hutang, Kinerja dan Nilai Perusahaan, Jurnal Akutansi dan Keungan, 9(1), 1-8.

Darwin Marasi Purba and Jhon Herlan Sianturi. Influence Analysis of Ownership Structure on Manufacturing Company's Performance in Indonesia 2012 - 2013 
Claessens, S., Djankov, S., Fan, J.P.H., and Lang, L.H.P. (2000). The separation of ownership and control in East Asian Corporations. Journal of Financial Economics, 58, 81-112.

Claessens, S., Djankov, S., Fan, J.P.H., and Lang, L.H.P. (2002 ). Disentangling the incentive andentrenchment effects of large shareholdings, Journal of Finance, 57(6),2741- 2771.

Cruthley, Claire, E., and Robert, S. (1989). A Test of Agency Theory of ManageriAL Ownership, Corporate Leverage, and Corporate Dividends". Financial Management, 18, 36- 46.

Cucculelli, M.and Micucci, G.(2008). Family Successionand Firm Performance Evidence from Italian Companies», Journal of Corporate Finance, 14(1).

Darwis, H. (2012). Manajemen Laba Terhadap Nilai Perusahaan Dengan Corporate Governance Sebagai Pemoderasi. Jurnal Keuangan dan Perbankan, 16(1), 4555.

Djabid, W. A. (2009). "Kebijakan Dividen, dan Struktur Kepemilikan Terhadap Kebijakan Hutang: Sebuah Perspektif agency Theory". Jurnal Keuangan dan Perbankan, 13(2), 249-259.

Dickinson, D.G. and Mullineux, A.W. (2001). Lessons from the East Asian financial crisis: a financial sector perspective. Georforum, 32(1), 133-142.

Douma S., George, R. And Kabir, R. (2006). Foreign and domestic ownership, business groups, and firm performance: evidence from a large emerging market, Strategic Management Journal, 27(7), 637-657.

Fauzi, A. (2006). Struktur kepemilikan saham asing di Indonesia. Gramedia Pustaka Utama. Jakarta.

Fauziah. (2011). Pengaruh Kepemilikan Pemerintah Terhadap Kinerja Keuangan BUMN yang Diprivatisasi Skripsi Fakultas Ekonomi UIN Malang, tidak dipublikasikan.

Farooque, Omar Al, Tony van Zijl, Keitha D., and AKM Waresul K. (2007). Corporate Governance in Bangladesh: Link between Ownership Financial Performance Blackwell Publishing Ltd, Journal Comilation, 15(6), 1453-1468. 
The Accounting Journal of BINANIAGA Vol. 04, No. 02, December 2019 p-ISSN: $2527-4309$, e-ISSN: $2580-1481$

$5^{\text {th }}$ Accreditation Rating: January 14, 2019 - January 13, 2024

This page intentionally be emptied.

Darwin Marasi Purba and Jhon Herlan Sianturi. Influence Analysis of Ownership Structure on Manufacturing Company's Performance in Indonesia 2012 - 2013 